\title{
Empowerment of Family Economy through the Program for Increasing the Prosperous Income Facilities in Tanah Laut Regency
}

\author{
Annisya Maresti Yanda ${ }^{1, *}$, Andi Tenri Sompa ${ }^{2}$, Ahmad Suriansyah $^{3}$ \\ ${ }^{1,2,3}$ Department of Administration Development, Lambung Mangkurat University, Indonesia
}

\begin{abstract}
The development requires directed actions for the improvement and improvement of the quality of human life, guidelines that can provide direction in development strategies as social policies designed for the welfare of the community and the quality of life of the community in order to meet social, economic, health and other public services needs including responsibility in providing services to the poor, providing guarantees to the community so as not to fall into poverty. This study includes descriptive qualitative with the aim of analyzing the implementation of the UPPKS program in family economic empowerment in Tanah Laut Regency, explaining the factors that affect the effectiveness of groups in the program UPPKS in family economic empowerment in Tanah Laut Regency and analyzed the success of the UPPKS program in family economic empowerment in Tanah Laut Regency. Scientific qualitative research methods concoct various information from objects and subjects in social research. From 11 sub-Regency in Tanah Laut Regency, in total, there are 135 villages and subRegency. The factors that influence the effectiveness of groups in the UPPKS program in family economic empowerment include (1) human factors, namely the level of member participation, member commitment, and leadership influence. (2) material factors, namely the availability of raw materials, availability of packaging materials, supporting equipment, product quality, and promotional activities. (3) method factors, namely communication, deliberation and consensus, division of tasks, openness, and the existence of standard operating procedures. (4) environmental factors, namely assistance to family planning officers/extension agents, the role of local government, banking / private sector/stakeholders.
\end{abstract}

Keywords - Community, Empowerment, Family Economy, Poverty, Tanah Laut Regency.

\section{INTRODUCTION}

Development is a systematic effort of various actors, both public, government, private sector, and other community groups at different levels to deal with interdependence and the interrelation of physical, socio-economic and other environmental aspects so that new opportunities to improve the welfare of local communities can be captured in a sustainable manner. Development requires directed actions for the improvement and improvement of the quality of human life, guidelines that can provide direction in development strategies as social policies designed for the welfare of the community and the quality of life of the community in order to meet social, economic, health and other public services needs including responsibility in providing services to the poor, providing guarantees to the community so as not to fall into poverty.

Factors that cause the condition of poor people and working people include small market and resource access, weak ability to use natural and human resources, unbalanced social structure and urban bias in the decision making process, and the allocation of funds. Empowerment of the poor to be independent in economic, cultural, and political terms is a major part of poverty alleviation (Soetomo, 2006). Poverty is not a phenomenon. Poverty is a reduced part due to vulnerability that has plagued many factors in the community even though many programs have been launched since the New Order government such as Desa Inpres disadvantaged Village (Inpres Desa terminal /IDT), Prosperous Family Savings (Tabungan Keluarga Sejahtera/Takesra), and Family Welfare Business Credit (Kredit Usaha Keluarga Sejahtera/Kukesra) oriented towards poor families (Sulistyani, 2004).

One of the efforts to overcome the problem of poverty requires the participation of women. Women's contribution to family income is very much needed to improve family welfare, and of course, it must also be supported by the government in making various efforts aimed at empowering women such as the existence of a forum or organization for women that are expected to play a role in development (Soetrisno, 1997). The role of women in development can realize Indonesian women who are advanced and independent in the economic field, including the UPPKS program through the National Family Planning Coordinating Board with the goal of Preprosperous families and Prosperous families I. The role of women is expected to be able to face problems faced and can be solved through organizations independently. And able to function as 
an effective lobbying force at the regional and national levels (Soetrisno, 1997).

UPPKS is a group of activities supporting family planning programs in the context of improving family welfare through entrepreneurial activities. The initial group was pioneered by BKKBN in 1979 under the name Business Acceptor Family Revenue Increase (Usaha Peningkatan Pendapatan Keluarga Akseptor/UPPKA). It aims to improve the economic conditions of family planning family members so that their lives will become more prosperous. One of UPPKA's bases is that without good conditions, it is impossible for families to improve their welfare, and these conditions must start from empowering families in the economic field. Thus, UPPKS is expected to become a model of micro-family businesses that function to move the wheels of the family economy through economic learning by arousing the interest and enthusiasm of the family for entrepreneurship (BKKBN, 2005).

In general, the UPPKS program can empower women/women in the economic field as an effort to increase poverty reduction, build self-reliance and family resilience, and create a small, happy, and prosperous family. Specifically, the UPPKS program can increase family empowerment in the economic field, train families, especially women to carry out entrepreneurial activities, improve family life dynamics, and enhance family participation in the implementation of development in their environment, increase family independence and resilience and increase poverty reduction efforts (BKKBN, 2010). According to the Operational Guidelines for the Implementation of UPPKA Activities from BKKBN (1986), the active and inactive indicators of UPPKS groups in carrying out activities include management, routine meetings, productive economic businesses, administrative records, guidance from the facilitator accompanying the group.

In Tanah Laut Regency, there are 52 UPPKS groups spread across eleven sub-Regency, and not all UPPKS groups are active, both in terms of group activities and productive group efforts. The development of the UPPKS group was constrained by the amount of capital provided and guidance from various parties, especially the DP2KBP3A Tanah Laut Regency, as the leading sector for this program and the inability of products to compete in a larger market. Revolving funds provided to the UPPKS group came from the Tanah Laut Regency Government grants with a limited amount of Rp.265,000,000, - so many groups that needed loans had to wait their turn. Based on data from the $\mathrm{KB}$ Counseling Center in Tanah Laut Regency, out of 52 groups, there are 24 active groups carrying out group activities in the form of savings and loans, monthly meetings, and running a household production business, while as many as 28 groups are not active.

\section{LITERATURE REVIEW}

\section{The concept of Poverty and its Prevention Strategy}

Data Poverty is a problem that has a heavy burden on development, which is characterized by vulnerability, helplessness, isolation, and the inability to express aspirations. The challenges faced in efforts to alleviate poverty are the demands to implement good governance management, regional autonomy, and decentralization, development in favor of the poor and development injustice and gender equality (Soetrisno, 1997). Population poverty is also the biggest national development challenge and is an indicator of success or failure for leaders in the region, moreover having natural resources that can provide prosperity for the people in the region they lead (Sarman et al., 2008).

Poor people are considered empowered if they are able to improve their socio-economic welfare through improving the quality of human resources, capital capacity, business development, and institutional joint venture by applying the principles of mutual cooperation, self-reliance, and participation (Prijono and Pranarka, 1996). In implementing the development process, the community is not only as an object but also as an actor in the formulation of a program and involved in the manufacturing process (Soetomo, 2006). Efforts to reduce poverty can be made through four strategic channels, including:

a) Expansion of opportunities, namely enabling the poor to get the widest opportunity in meeting basic needs and improving living standards in a sustainable manner,

b) Community empowerment namely strengthening social, political, economic, and cultural institutions and expanding the community participation of the poor in making public policy decisions that guarantee respect, protection, and fulfillment of basic needs,

c) Increase capacity, namely to develop the basic abilities and ability of the poor to take advantage of environmental development,

d) Social protection, namely providing protection and a sense of security for vulnerable groups (women head households, poor people, elderly people, neglected children and people with disabilities) and new poor people caused by natural disasters, the negative impact of the economic crisis and social conflict (Wrihatnolo, 2008).

According to the Ministry of PP and PA (2006), the poverty approach includes: 
a) Cultural poverty, which is a phenomenon of structural inequality in the form of women's limitations in accessing education and economic access that still prevails in the community,

b) Structural poverty which starts with the emergence of cultural poverty in the form of low education and the majority of skills women,

c) Natural poverty, namely the existence of some women who are resigned to their position in the community and household and are aware of their nature as women.

Problems faced by micro-scale women entrepreneurs include (1) lack of access to market information and technology, (2) lack of access to capital, (3) lack of improvement in human resources, (4) lack of institutional and network management and (5) lack of gender sensitivity among the people.

\section{The Concept of Empowerment}

According to Prijono (1996), the household is the main source of empowerment, and there are three strengths in the household, namely social, political, and psychological. Social power involves access to certain production bases such as information, knowledge and skills, participation in social organizations, and financial resources. Political power concerns access to decision making that affects the future of the household. The power of psychology is the potential of individuals who show confident behavior.

The notion of development that prioritizes community empowerment is understood as a process of transformation in social, economic, cultural, and political relations of the community. Changes in a structure that occur naturally must be able to produce and be enjoyed together. This process is expected so that community empowerment can increase community (capacity building) through the creation of capital accumulation from the surpluses generated and, in turn, can create income that is enjoyed by the community, and this process is driven by the community themselves. Empowerment comes from participation, and all people have the right to express opinions in decision making related to their lives so that they become tools for normative development goals such as social justice, equality, and democracy (Mikkelsen, 2003).

According to Luttrell (2009), economic empowerment seeks to ensure that people have the appropriate skills, abilities, and resources as well as access to sustainable income and livelihoods. The scope of community empowerment activities includes:

a) Human development, by developing individual capacity, developing institutional or institutional capacity and developing system capacity,

b) Business Development, by selecting commodities and types of business, feasibility studies and business planning, the establishment of business entities, investment planning and determination of resources- sources of funding,

c) Community development and institutional development, with a group of people, clearly identified, there are goals to be achieved, there are rules that are adhered to and binding, there is an organizational structure towards local institutions towards improving living standards, productivity, creativity, knowledge, and skills as well as institutional capacity.

According to Mardikanto and Soebiato (2012) institutions have five characteristics, namely: (1) with regard to something permanent, (2) relating to abstract things that determine behavior, (3) relating to how to act in society, (4) emphasizing behavior patterns that are agreed upon and have sanctions, (5) are ways to solve problems. Stages of community empowerment activities include (1) site selection, (2) socialization of community empowerment, (3) community empowerment process, (4) community independence (Delivery, 2004).

\section{Institutional Strengthening in the Empowerment Context}

Data According to Hardjito (1995), organizations are social units that are consciously coordinated, enabling members to achieve goals that cannot be achieved through individual actions separately, which include the structure, hierarchy, and process of organizational activities that can unite and group people. Social groups are social entities consisting of two or more people who carry out social interactions that are quite intensive and orderly so that there is a division of tasks, structures, and certain norms. This is consistent with the concept of UPPKS, which is a group that carries out various small-scale productive economic business activities aimed at increasing family income and realizing the institutionalization and civilization of the Normally Prosperous Small Family Norms (NKKBS) in the community through group dynamics (Santosa, 2004).

According to Utomo et al. (2006), the determining aspect of the government's success in carrying out development tasks is the existence of effective institutions and optimal performance. Institutional restructuring is needed to achieve the success of the development program by looking at indicators of the government's ability to serve the needs of the community and utilize resources optimally. 
Strengthening institutional capacity must pay attention to aspects including:

a) Aspects of human resources will encourage the realization of institutional goals more effectively and efficiently.

b) Financial aspects will reduce waste and consider allocating resources efficiently by increasing creativity, entrepreneurship, initiative, and increasing financial transparency.

c) Technological aspects will speed up the process of completion of the work.

d) Aspects of service needs will adjust the needs of the region concerned.

e) Aspects of strategic value, as outlined in the vision and mission of the institution.

According to Huraerah and Purwanto (2005), institutions contain two meanings, namely institutions and organizations. Institutional is a form of relations between two or more people, two groups of people, or the relationship of people with community groups in the use of resources and distribution. When viewed from an institutional understanding, the UPPKS is included in the institutional organization, which includes elements including; (1) rules of the game, (2) regulation of rights and obligations, (3) boundary boundaries, (4) sanctions. In addition, UPPKS also has four characteristics, namely: (1) the existence of a structure, (2) clear objectives, (3) having participants, (4) technology, and (5) resources.

According to Danim (2012), effective groups are directly related to the achievements of community groups, and their existence is reflected in their ability to achieve. Effective groups can meet the needs of their members. Small groups of 4 to 22 members are more cohesive than larger groups. The range of cohesiveness of small groups is greater than in large groups. When compared to UPPKS group membership, UPPKS is included in the small group category. This is indicated by the number of group members ranging from 10 to 20 group members.

According to Syahyuti (2007), there is no specific form of institution for empowerment, but there are certain elements so that empowerment can be successful. Some key institutional developments for empowerment include (1) access to information, (2) inclusiveness and participation, (3) accountability, and (4) local organizational development. Institutional development also works on five areas, namely: (1) providing basic services, (2) increasing the capacity of local government, (3) increasing national government capacity, (4) developing propoverty markets, and (5) developing access to justice assistance and law. Direct institutional effectiveness is the level (1) participation in institutions, (2) the role of outsiders, (3) formal education, and (4) the influence of local leadership (Anantanyu et al., 2009).

\section{METHODOLOGY}

Methods of Data Collection Methods

To obtain the data needed in this study was conducted using data collection techniques as follows:

1) Interviews, namely by conducting a question and answer with authorities such as :

a) $\mathrm{KB}$ Division that handles UPPKS programs at the P2KBP3A Office in Tanah Laut Regency.

b) UPPKS group members.

2) Observation, namely observing the UPPKS group that will be examined. Data collection is based on accessibility, namely active and inactive groups, each taken from one of the sub-Regency closest to the capital city of Tanah Laut, and active and inactive groups each one from the sub-Regency with access far from the Regency capital.

3) Verification is to check the correctness of the data obtained from the sample UPPKS group that will be examined.

Based on the map of Tanah Laut Regency, the closest sub-Regency to the capital of Tanah Laut Regency is Pelaihari Regency, Bajuin Regency, and Tambang Ulang Regency. While the Kecamatan area with long distances and difficult access from the Regency capital is the Kintap and Jurong Regency. So that for the sampling will be taken two active groups and two inactive groups from rural Regency, as well as two active groups and two inactive groups from urban Regency. The groups to be sampled from the Regency mentioned above are as follows:

1) Mekar Sejahtera Group from Batalang Village, Jorong Regency and Sri Rejeki Group, Durian Village, bent down as a sample of active groups representing rural Regencys.

2) Potato group from Kebun Raya village, Kintap sub-Regency and Ruhui Rahayu subRegency, Bumi Makmur sub-Regency as a sample of inactive groups representing rural sub-Regency.

3) Mitra Sejahtera group from Pemuda village, Pelaihari sub-Regency and Apsari Makmur group, Gunung Makmur village, Takisung sub-Regency as a sample of active groups from urban sub-Regencys.

4) Mekar Sari group, Gunung Mas village, Batu Ampar sub-Regency and Damai Kencana group, Angsau sub-Regency, Pelaihari sub-Regency as samples of inactive groups from urban sub-Regencys. 


\section{Unit of Analysis}

In this study, the unit of analysis is the UPPKS group in the Tanah Laut Regency. From the initial data obtained, then samples will be taken with a purposive sampling technique to be able to provide a comprehensive understanding of the symptoms studied and free the researcher to choose who is found to test ideas on the subject of interest (Indrawan and Yaniawati, 2014). The aim is to obtain data on active groups, and inactive groups related to indicators of institutional effectiveness consisting of the achievement of goals, functions and roles, innovation, and sustainability as a key informant is one group member. Furthermore, this research will also verify the parties directly related to the UPPKS group, namely the Family Planning Instructor, who is tasked with fostering the village of the UPPKS group that is the research sample.

\section{Research Instruments}

The instruments used in this study were interview and observation guidelines, as well as secondary data obtained from the Dinas P2KBP3A Tanah Laut Regency.

1) Interview guidelines Interview

Guidelines are used so that the interviews conducted do not deviate from the research objectives. This guideline was compiled not only based on research objectives but also based on theories related to the problem under study, namely the implementation of UPPKS.

2) Observation guidelines Observation

Guidelines are used so that researchers can make observations in accordance with the objectives of the study. Observation guidelines are based on the results of observations on the subject's behavior during the interview and observations on the environment or interview settings, as well as their influence on the subject's behavior and the information that appears during the interview.

\section{Time and Location of Research}

This activity was carried out at UPPKS groups in Tanah Laut Regency. The research was carried out in 2017 and the writing of the research report in April 2020 .

\section{Data}

The data analysis used is the fishbone diagram. Which diagram will identify various potential causes of UPPKS inactivity? Based on 4 (four) categories, namely humans, capital, machinery, and the environment. So that the root of the problem is found, from interviews with respondents, the four categories will be described in order to obtain the root causes that affect the effectiveness of the UPPKS group. The effectiveness of the group greatly influences the success of the family economic empowerment program through the UPPKS group in 2020.

\section{RESULTS}

\section{The Overview of Tanah Laut Regency}

Geographically, Tanah Laut Regency is located at the coordinates of $114^{\circ} 30^{\prime} 54,663^{\prime \prime}-115^{\circ} 22 ' 38,535^{\prime \prime}$ East Longitude and $3{ }^{\circ} 30^{\prime} 37,586$ "-4 ${ }^{\circ} 10^{\prime} 41,134 "$ Latitude South. Based on the Tanah Laut Regency RTRW in 2016-2036, the land area of Tanah Laut Regency is 384,852 hectares, with the regency capital in Pelaihari Regency. The boundaries of the Tanah Laut Regency are as follows; in the north bordering Banjar Regency and Banjarbaru City; the south borders the Java Sea; in the east bordering the Java Sea and Tanah Bumbu Regency, and to the west bordering the Java Sea.

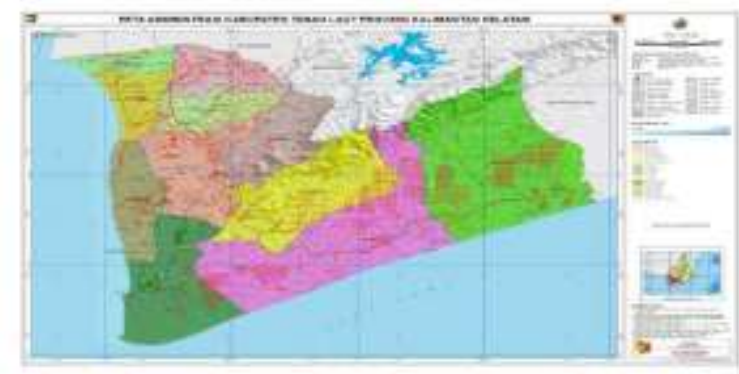

FIGURE 1. Administrative Region of Tanah Laut Regency.

Source: RTRW of Tanah Laut Regency in 2016-2036.

The scope of the administrative area of Tanah Laut Regency covers 11 Regency, namely Bati-Bati Regency, Bumi Makmur SubRegency, Kurau SubRegency, Kurau SubRegency, Bajuin SubRegency, Bajuin SubRegency, Pelaihari SubRegency, Takisung SubRegency, Panyipatan Regency, Batu Ampar Regency, Jorong Regency, and Kintap Regency. The Regency with the largest area in Tanah Laut Regency is the Jorong Regency, with an area of 81,639 hectares (21.2\%). Kintap Regency is in the second position, with an area of 76,319 hectares (19.8\%). In the third and fourth positions, Batu Ampar and Panyipatan subRegencys occupied an area of 45,908 hectares (11.9\%) and 40,613 hectares (10.6\%). Meanwhile, Bumi Makmur Regency is the smallest area in Tanah Laut Regency, which is $9,542(2.5 \%)$. 
TABLE 1. Land Area of Tanah Laut Regency by SubRegency

\begin{tabular}{|llcc|}
\hline No & SubRegency & Area (Hectares) & Percentage (\%) \\
\hline 1 & Jorong & 81,639 & 21.2 \\
2 & Kintap & 76,319 & 19.8 \\
3 & Batu Ampar & 45,908 & 11.9 \\
4 & Panyipatan & 40,613 & 10.6 \\
5 & Pelaihari & 31,871 & 8.3 \\
6 & Kaihin & 26,529 & 6.9 \\
7 & Takisung & 21,652 & 5.6 \\
8 & Bati-Bati & 20,021 & 5.2 \\
9 & Tambang Ulang & 17,464 & 4.5 \\
10 & Kurau & 13,294 & 3.5 \\
11 & Bumi Makmur & 9,542 & 2.52 .5 \\
& & & $100.0 \%$ \\
\hline
\end{tabular}

Source: RTRW Tanah Laut Regency, 2016-2036

From 11 sub-Regency in Tanah Laut each, while the sub-Regency with the smallest number Regency, in total, there are 135 villages and sub- of villages is Tambang Ulang Regency and Bajuin Regency. The regions that have the highest number of Regency with a total of 9 villages each. Details of the villages and kelurahan are Pelaihari Regency (15 number of villages by Regency in Tanah Laut villages and 5 kelurahan), Bati-Bati Regency, Batu Regency are shown in the following:

Ampar Regency, and Kintap Regency with 14 villages

TABLE 2. Division of Administrative Areas of Tanah Laut Regency

\begin{tabular}{|lllll|}
\hline No. & SubRegency & Capital City & \multicolumn{2}{c|}{ Village / Sub Village } \\
\hline 1. & Panyipatan & Panyipatan & 10 & - \\
2. & Takisung & Gunung Makmur & 12 & - \\
3. & Kurau & Padang Luas & 11 & - \\
4. & Bumi Makmur & Handil Babirik & 11 & - \\
5. & Bati-Bati & Padang & 14 & - \\
6. & Tambang Ulang & Tambang Ulang & 9 & - \\
7. & Pelaihari & Pelaihari & 15 & 5 \\
8. & Bajuin & Baju & 9 & - \\
9. & Batu Ampar & Batu Ampar & 14 & - \\
10. & Jorong & Jorong & 11 & - \\
11. & Kintap & Kintapura & 14 & - \\
\hline
\end{tabular}

Source: RTRW of Tanah Laut Regency in 2016-2036

\section{DISCUSSION}

Implementation of the UPPKS Program in Family Economic Empowerment in Tanah Laut Regency. The empowerment of the family economy to develop and be independent requires a long process in accordance with the stages of empowerment. As for the things that have been carried out by the P2KBP3A Office as the leading sector for the extension of the BKKBN that implements the UPPKS program in the context of empowering the family economy in the Regency, among others: 
1) Selection of locations or areas

Each sub-Regency in Tanah Laut Regency has an UPPKS group, but not all villages have such groups. In 130 villages and 5 subRegency in Tanah Laut, there are only 52 groups. This means that areas deemed necessary and potential cadres are formed by UPPKS. On average, the UPPKS group administrators were drawn from IMP cadres, namely PPKBD or Sub PPKBD Desa. This may occur because PKB is easier to communicate and provide guidance to existing cadres rather than looking for other cadres outside the IMP cadres. Because not all community members are interested in social activities. However, this could also occur due to a lack of socialization from the local village coach. Judging from a large number of UPPKS groups but more than $50 \%$ are not active, from interviews with respondents that this group is a group inherited from previous PKBs, most of whom have retired, changed assignments, or moved agencies out of BKKBN or from DP2KBP3A. Only groups that are truly potential and fostered by competent PKB are able to survive their activities and business.

\section{2) Socialization of community empowerment}

The P2KBP3A office conducts socialization related to empowerment carried out through PKB field officers as facilitators, namely in the form of delivery of related programs in the UPPKS group. In the socialization of empowerment, awareness was made to the community who were members of the UPPKS that they had skills that could be used for productive economic business and fostered willingness in-group members to participate in or take part in beneficial empowerment activities.

\section{3) Community empowerment process}

After the formation of the UPPKS group, the empowerment process was carried out with several activities, including identifying and assessing the potential of the area and the opportunities and desires of the members. What business do the members want to run and how is the implementation process. After that, a plan is drawn up for how the business will be carried out. When the members have got a business idea, then the plan that has been prepared is applied in group activities. To expedite the running of the group business, a capital loan from the P2KBP3A Office is given in the amount of Rp.10,000,000.-. However, for the new group, the initial loan was only Rp. 5,000,000, - only. According to the BKKBN Family Economic Empowerment Directorate (2015), the source of business capital comes from membership fees, member savings/savings, remaining income from existing businesses, and small risk loans. Groups that do business continue to receive guidance and assistance at the village and sub-Regency levels by PKB, as well as at the Regency level from DP2KBP3A in the field of KB KS apart from coaching routinely carried out by $\mathrm{PKB}$. DP2KBP3A also carries out cross-sectoral cooperation such as BLKs to conduct training for groups. The training aims to improve the skills and abilities of UPPKS members. Apart from being provided with capital, coaching, and training, groups with good achievements in their activities and administration will be selected to take part in competitions held annually by the central BKKBN. Selection is carried out from the sub-Regency level, where representatives from each subRegency will be assessed by the Regency team. Competition winners from the Regency level will be proposed again to participate in the competition at the provincial level. In this case, the assessment will be carried out by the BKKBN Representative for South Kalimantan Province. And if they pass the selection at the provincial level, the group will be included again in the national competition. In addition to selecting the best UPPKS, this competition activity is also a trigger for groups to continue to develop and be more creative in group activities.

\section{4) Community Self-Reliance}

After the formation of the group and the running of the business, DP2KBP3A, through the facilitator, in this case, the Village Supervisory $\mathrm{PKB}$, continues to carry out coaching and monitoring of business activities for the sake of creating community independence. At this stage, the community is given the freedom to take action to develop themselves so that an independent society can be realized. Community independence can increase the standard of living because they are truly capable of managing their own activities (Mardikanto and Soebiato, 2012). The P2KBP3A office makes efforts to make 
the community independent by holding meetings or visits to the UPPKS group to see group development, supervise, and foster groups through competition activities which are held annually.

Factors affecting the effectiveness of groups in the UPPKS program in empowering the family economy in Tanah Laut Regency. Based on the fishbone diagram, the causes of the lack of effectiveness of the UPPKS group in Tanah Laut Regency can be described by looking at 4 main factors, namely: people, materials, methods, and the environment. Each of these main factors can be identified as the main cause, which resulted in the ineffectiveness of the UPPKS group in empowering the family economy. The main causes of human factors include the influence of leadership, member commitment, formal education of members, level of member participation, and job performance. Meanwhile, material factors that resulted in the lack of effectiveness of the UPPKS group were caused by raw materials, packaging materials, supporting equipment, product quality, and promotional activities.

Another main cause is the method factor, including communication, division of tasks, openness, deliberation, and consensus, and SOPs. Environmental factors include family planning officers/extension agents, business competitors, consumers, local governments, banks / private parties/stakeholders. The effectiveness of the UPPKS group can also be measured by looking at the activeness of the UPPKS group in empowering the family economy. According to observational data, from a number of 52 UPPKS groups, there are 24 active groups and 28 inactive groups.

The ineffective UPPKS group was caused by several factors, among others:

1) Human factors.

From the results of interviews with respondents, several problems were found related to human factors, namely:

a) Lack of member participation. Ideally, the UPPKS group is active in conducting meetings or at least effective communication between members.

b) Lack of member commitment. At the beginning of group formation, there must be a commitment agreed upon by the members. From the interviews with the inactive group, it was found that there was no commitment at the beginning. This is because the PKBs at the beginning of the program's launch is required to meet the target number of groups in the fostered village.

c) The influence of leadership in the group. The group leader has a strong influence on the sustainability of the group. If the group leader or core committee is unable to carry the group, of course, the group will become inactive. Another thing that can be taken. For example, the group is inactive due to the group leader who previously actively coached it when he was still an honorarium teacher when he was appointed as a civil servant teacher, several activities, and demands for the obligation to cause the group to abandon the group.

According to Rofai (2006), leadership is one of the factors that influence organizational effectiveness, because leadership is related to the process of influencing and mobilizing all members of the organization so that they work to achieve organizational goals. In an organization, there also needs to be a unity of orders, because, without unity of orders, it will cause confusion, doubt, and also lead to unclear responsibilities. The lines of a command unit should clearly indicate who a person is taking orders from and to whom he is responsible. The effectiveness of each organization is greatly influenced by human behavior because it is a common resource for all organizations. Organizational performance depends on individual performance, and managers/leaders must have more than just knowledge in terms of determining individual performance (Rofai, 2006).

2) Material factors In this factor, the things that affect the inactivity of the group are:

a) Unavailability of sufficient and quality raw materials. Several groups conducting productive businesses rely only on raw materials from local products. As an example of a group that produces melinjo chips, the raw material for melinjo fruit is only obtained from the village. In the past, the yield of melinjo in that village was abundant. Over time, the melinjo garden was reduced, and the harvest was not much, so they could not meet consumer demand.

b) We are supporting equipment for simple production and marketing 
processes, still using traditional materials. For example, in the process of making herbal extracts, shredded by hand, and manual manufacturing processes without machines.

c) Promotion to market the product optimally, there have been no concrete steps to market products outside the village other than product exhibition activities. This means that there is no continuity of product introduction in a specific place.

Effectiveness can be realized if it shows that produce raw materials are always available so that there are no obstacles in meeting market needs. The production process describes how the development process of a thing can affect the results. The process is an element that has an important role in processing input in order to produce output that is beneficial to society. This process can be carried out by a machine, person, or computer and is a system component that has the main role of processing input to produce output that is useful for the users (Sutanta, 2003).

3) Method factors, among the method factors that affect group effectiveness, namely:

a) Poor communication between fellow group members, all members are required to agree in terms of a group arrangement. The absence of openness also causes poor communication between members.

b) The absence of deliberation to reach consensus in every decision making, for example, in the case of a revolving loan proposal, an agreement of all members is required with the signature of the joint responsibility agreement. If there are members who do not want or object to the agreement, the proposal cannot be forwarded.

c) The existence of disclosure of information and reports that support the success of the group,

d) The existence of standard operating procedures that can be used as guidelines in every process of implementing the UPPKS group business.
According to Suranto (2011), communication is the process of transferring information or messages and understanding from one person to another. One type of communication with a high frequency of occurrence in human life is interpersonal communication or interpersonal communication, including in organizational life. Interpersonal communication can establish good relationships with group colleagues, build cooperation and synergy with colleagues, deliver tasks and direct performance to suit goals, and overcome differences of opinion, tension, and conflict (Hardjana, 2003).

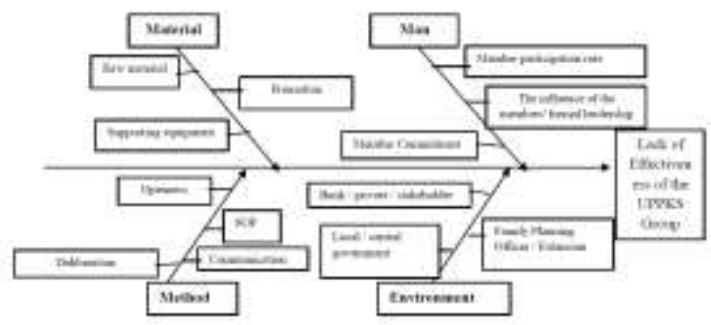

FIGURE 2. Fishbone Diagram for the Effectiveness of the UPPKS Group

Refereeing from the chart above, the factors that are considered the most dominant in influencing the effectiveness of the group are humans and the environment. Because group activities will run well and effectively if managed by competent administrators and members who support each other. While environmental factors are also very influential, this can be seen from the guidance carried out from the village to the central level must be mutually exclusive and sustainable.

\section{The Level of Success of the UPPKS Program in Family Economic Empowerment}

Factors that affect the success rate of the UPPKS program include:

1) Community

Participation in an empowerment program is very important. If a program has a high level of community participation, the program will achieve success, and vice versa, if the level of community participation is low, the program has not yet achieved success. The level of community participation can be maximized by conducting socialization activities of the UPPKS Program among the community so that the community can understand the UPPKS program. In addition, there are still many people who underestimate this UPPKS program. The community considered that the income from the UPPKS program would not be able to meet the basic needs of the family. From the 
results of interviews with respondents, the increase in community participation in the UPPKS group generally did not increase significantly. Group members did not experience significant additions or changes. In fact, it could be said that they were.

\section{2) UPPKS Income Level}

When discussing an economic business activity, both micro and macro businesses, it will discuss the income obtained from these business activities, whether the results are profit or loss. Not all results from business activities have been profitable, but some have experienced losses. This condition is due to various factors, including a lack of resources for production materials, weak business actors in managing their businesses, and not having a fixed distribution or marketing outlet. From the results of interviews with several group members who were engaged in productive businesses, they were able to get additional income from selling vegetables, snacks, and so on. However, the results of the business are inadequate due to marketing constraints, which only cover the neighborhood where they live, such as the production of pecel spices which are only sold in neighboring stalls, pastries that are only made when there is an order. However, at least from their existing business, they get additional income from before the existence of business activities.

\section{3) Level of Family Welfare}

Changes in the quality of community life for the better are an indicator of a more prosperous society by increasing family income, fulfilling food needs, clothing, and shelter, the health of family members, easy access to health services, ease of children's education and easy access to transportation facilities. If all these aspects have been fulfilled by a family, then the family can be said to be a prosperous family. According to the BKKBN, family welfare has different level classifications ranging from PreProsperous Families, Prosperous Families I, Prosperous Families II, Prosperous Families III, and Prosperous Families III Plus. Each level has different indicators according to the family's ability to meet their needs. The existence of the UPPKS group, especially in Tanah Laut Regency, has, in fact, not been able to improve family welfare. This can be seen from the results of interviews with key informants who argue that the small amount of capital provided has not been able to meet production needs. Production is carried out only on a small scale, the products produced are only to meet the needs of stalls, or demand when there is an expo exhibition. Meanwhile, for groups that carry out a savings and loan business, usually loans only for additional business capital are not able to meet all capital needs.

\section{The UPPKS Program in Family Economic Empowerment}

Efforts to Increase Prosperous Family Income (UPPKS) are groups that carry out productive economic activities to increase family income in order to create a happy and prosperous small family with members, both mothers/women from underprivileged families, prosperous families I, and other families with higher welfare levels. High, whether it is not, moderate, or full family planning participants. The general objective of the UPPKS group is to empower mothers/women in the economic sector as an effort to increase poverty reduction in order to build family independence and resilience as well as to create small, happy, and prosperous families. Specifically, the objectives of the UPPKS group are:

a) Increase family empowerment in the economic field.

b) Train families, especially women, to carry out entrepreneurial activities.

c) Increase the dynamics of family life.

d) Increase participation in the implementation of development in their environment.

e) Increasing the independence and resilience of the family.

f) Increasing poverty reduction efforts.

The direct targets of this program are women who belong to the pre-prosperous family, I prosperous family category, and other families whose welfare level is higher than those who are carrying out productive economic business activities. The indirect targets of this activity include development cadres at the village level, community leaders, PLKBs, and capital lenders.

The development of UPPKS activities and the main activities carried out are as follows:

1) Communication, Information, and Education. This activity is aimed at fostering concern and commitment from various elements of development in each environment so that 
participation in the implementation of prosperous family development develops.

2) Prosperous family data collection. This activity is carried out every year with the community to obtain complete data on the level of family welfare so that those belonging to the prosperous pre-family family and the first prosperous family can immediately improve their welfare through the UPPKS group.

3) Guidance for the development of productive economic enterprises. This guidance is carried out through the UPPKS group with the type of business (1) family commuters (picking, processing, selling, and making profits by the family), (2) family advancing (processing, packing, selling, and making profits by the family), (3) services, such as beauty salon businesses, offerings, masseurs / meaningful, and tailors.

4) Business partnership. Pokjanal, at a higher village level, is trying to find business partners for the UPPKS group in developing their businesses. Partnership patterns can be in the form of plasma nucleus, subcontracting, agency, franchise, general trading, and joint ventures.

In the implementation of the UPPKS program driven by the BKKBN, the criteria used to determine which families will receive assistance in this program are the criteria issued by the BKKBN. The indicators used are indicators found at the stages of a prosperous family. The indicators of the stages of a prosperous family are described in detail as follows:

Stage I prosperous family a family will be classified as a family with the category I prosperous family if it fits the following criteria:

1) The family performs worship according to the teachings of their respective religions.

2) In general, the whole family eats two or more times a day.

3) All family members have different clothes.

4) The widest part of the floor of the house is not from the ground.

5) If a child is sick and PUS wants to be a family planning acceptor, they are taken to modern medical facilities.

If one or more of these indicators is not met, then the family is classified into a poor family. The
BKKBN criteria for those classified as poor are those in the first prosperous family and pre-prosperous families.

\section{Factors that influence group effectiveness in the UPPKS program in empowering the family economy}

According to Huraerah and Purwanto (2005), humans develop and improve through groups. However, not all groups can improve a person's quality. Only effective groups can improve human quality. Effective groups have three basic activities, namely:

1) Activities to achieve goals.

2) Activities maintain the group internally.

3) Activities change and develop ways of increasing group effectiveness.

The interaction of group members that shows activities by integrating the three kinds of basic activities is to reflect that the group can be categorized as a successful or effective group. Effective group members have the skills to overcome or remove obstacles to the achievement of group goals, to solve problems in maintaining and improving the quality of interactions among group members, and skills to overcome obstacles to increase in order to make the group more effective (Huraerah and Purwanto, 2005). The effectiveness of the Implementation of the Business Program for Increasing Prosperous Family Income can be measured through the following indicators:

1) Sources of information from respondents about the UPPKS program.

2) Respondents' understanding after obtaining information on the UPPKS program.

3) Parties who invite/encourage to join the UPPKS program.

4) Respondent's knowledge of the UPPKS program administrators.

5) Respondent's knowledge of the UPPKS program implementation process.

6) Respondents' knowledge of the UPPKS program targets.

7) Respondents' knowledge of the UPPKS program objectives.

8) Respondent's knowledge of the source of funds for the UPPKS group's business. 
9) Respondents' knowledge of capital and institutions.

10) Types of business developed by the UPPKS group.

11) Other types of businesses that want to be developed through the UPPKS program.

12) Communication and information forum among UPPKS participants.

Accuracy of targeting, including:

1) Respondents who are prioritized are family planning acceptors.

2) Respondents belong to poor families based on the BKKBN criteria.

3) Whether or not the respondent received assistance.

4) Respondents are recorded as poor families at the village office.

Timeliness, including:

1) The year the respondent was a member of the UPPKS group.

2) Information will hold outreach on the UPPKS program.

3) Time for deliberation on the formation and implementation of the UPPKS program.

4) The time for providing guidance or counseling to respondents after becoming a member of the UPPKS group.

The timing of the assistance was matched with the time the UPPKS group's business was running.

1) Frequency of assistance and timing of assistance.

2) Loan refund frequency.

The achievement of targets, including:

1) Suitability of the UPPKS program with the wishes.

2) In accordance with efforts to improve the family economy.

3) Implementation of the family planning program well.
4) Increased enthusiasm for life, work, and business for mothers since joining the UPPKS program.

5) The target group members plan each year.

6) Whether or not the target has been achieved.

7) Help or not in meeting and financing the necessities of life.

Achievement of objectives, including:

1) Increasing family empowerment in the economy.

2) Train families, especially women, to carry out entrepreneurial activities.

3) Improve the dynamics of family life.

4) Increase family participation in the implementation of development.

5) Increase the independence and resilience of the family.

6) Increase poverty reduction efforts.

\section{CONCLUSIONS}

Based on the objectives and results of the study, the following conclusions are obtained:

1) Implementation of the UPPKS program in Tanah Laut in the economic empowerment of the family basically has not been able to help the family economy, increase family income, develop group dynamics, increase family planning participation, develop family independence, and strengthen family planning.

2) The factors that influence the effectiveness of groups in the UPPKS program in family economic empowerment include (1) human factors, namely the level of member participation, member commitment, and leadership influence. (2) material factors, namely the availability of raw materials, availability of packaging materials, supporting equipment, product quality, and promotional activities. (3) method factors, namely communication, deliberation and consensus, division of tasks, openness, and the existence of standard operating procedures. (4) environmental factors, namely assistance to family planning officers/extension agents, the role of local 
government, banking / private sector/stakeholders.

3) The level of success of the UPPKS program in family economic empowerment can be seen from the level of community participation, the income level of UPPKS members, and the level of family welfare. 6.2 .

Based on the objectives and results of the study, the following suggestions are obtained:

1) Collaborating with regional banks regarding the continuity of group businesses with low interest and a ceiling that is in accordance with the group's business capabilities.

2) Provide training and mentoring according to the group's business fields routinely and thoroughly to all UPPKS groups in Tanah Laut.

3) Coaching is carried out continuously from the village level to the central level so as to spur group effectiveness.

4) Facilitating product marketing, good packaging, obtaining product permits, and others.

\section{REFERENCES}

[1] Ach. Wazir Ws., et al. 1999. Panduan Penguatan Menejemen Lembaga Swadaya Masyarakat. Jakarta: Sekretariat Bina Desa dengan dukungan AusAID melalui Indonesia HIV/AIDS and STD Prevention and Care Project.

[2] Adi, Isbandi Rukminto. 2008. Intervensi Komunitas Pengembangan Masyarakat Sebagai Upaya pemberdayaan Masyarakat. Rajagrafindo Persada. Jakarta.

[3] Allison, Michael; Kaye, Jude. 2005. Perencanaan Strategis Bagi Organisasi Nirlaba. Yayasan Obor Indonesia. Jakarta.

[4] Anantanyu, Sapja; Sumardjo; Slamet, Margono; Tjitropranoto, Prabowo. (2009). Faktor-Faktor Yang Mempengaruhi Efektivitas Kelembagaan Petani (Kasus di Provinsi Jawa Tengah). Jurnal penyuluhan, Maret 2009 Vol.5 No.1. Diakses pada 2 Desember 2016.

[5] Badan Pendidikan dan Pelatihan Keuangan Kementrian Keuangan. 2003. Tehnik Ilustrasi Masalah-Diagram Fishbone. http://www.bppk.kemenkeu.go.id/publikasi/artikel/418artikel-soft competency/10999-teknik-ilustrasi-masalahfishbone-diagrams. diakses pada tanggal 26 Maret 2020.

[6] BKKBN, 1986. Pedoman Operasional Pelaksanaan Kegiatan UPPKA. Deputi Bidang Pembinaan Operasional Program. Jakarta.

[7] BKKBN, 1993, Undang-Undang Nomor 10 tahun 1992 tentang Perkembangan kependudukan dan pembangunan keluarga sejahtera, Jakarta.

[8] BKKBN, 2015. Delapan Langkah Tingkatkan Penghasilan Keluarga Menuju Ekonomi Kuat dan Mandiri. Direktorat Pemberdayaan Ekonomi Keluarga. Jakarta.

[9] Danim, Sudarwan. 2012. Motivasi Kepemimpinan dan Efektifitas Kelompok. Rineka Cipta. Jakarta

[10] Diana Sulistyorini(2006).Pengaruh Lingkungan Kerja Fisik Dan Pengawasan Terhadap Efektivitas Kerja Pegawai Pada
Dinas Pekerjaan Umum Dan Lalu Lintas Angkutan Jalan Kab. Karanganyar Tahun 2006

[11] Dirgantoro, Crown. 2001. Manajemen Strategik Konsep, Kasus dan Implementasi. Grasindo. Jakarta.

[12] Gusfrianti, Reni, Rahmita Budiartiningsih. 2010. Peranan Program Usaha Peningkatan Pendapatan Keluarga (UP2K) terhadap Peningkatan Pendapatan Keluarga di Kecamatan Cerenti Kabupaten Kuantan Singingi. Jurnal Ekonomi Universitas Riau.

[13] Hardjana, AM (2003). Komunikasi intrapersonal \& komunikasi interpersonal. Yogyakarta: Kanisius.

[14] Hardjito, Dydiet. 1995. Teori Organisasi dan Teknik Pengorganisasian. Rajagrafindo Persada. Jakarta.

[15] Hasim dan Remiswal. 2009. Community Development Berbasis Ekosistem. Diadit Media. Jakarta.

[16] Heryendi, WT, \& Marhaeni, AI 2013. Efektivitas Program Usaha Peningkatan Pendapatan Keluarga Sejahtera (UPPKS) di Kecamatan Denpasar Bali. Jurnal Ekonomi Kuantitatif Terapan, 78-85.

[17] Dr. A. Arun Prakash, "A Qualitative Analysis on SocioEconomic and Health Background of the Elderly Tribes in Pachamalai Hills of Tiruchirappalli District of Tamilnadu" SSRG International Journal of Economics and Management Studies 4.6 (2017): 52-57.

[18] Huraerah, 2008. Pengorganisasian dan Pengembangan Masyarakat: Model dan Strategi Berbasis Kerakyatan. Bandung: UNPAS Press. $232 \mathrm{hlm}$.

[19] Indrawan, Rully dan Yaniawati, Poppy. 2014. Metodologi Penelitian. Refika Aditama. Bandung.

[20] Kementrian Pemberdayaan Perempuan dan Perlindungan Anak. 2012. Kebijakan Peningkatan Produktivitas Ekonomi Perempuan. Deputi Bidang Pengarusutamaan Gender Bidang Ekonomi. Jakarta.

[21] Liana, Y. 2016. Peran Ibu Dalam Meningkatkan Pendapatan Keluarga Untuk. Jurnal Dinamika DotCom, 85-94.

[22] Mardikanto, Totok dan Soebiato, Poerwoko.2012. Pemberdayaan Masyarakat Dalam Perspektif Kebijakan Publik. Alfabeta. Bandung.

[23] Mikkelsen, Britha. 2003. Metode Penelitian Partisipatoris dan Upaya-upaya Pemberdayaan. Yayasan Obor Indonesia. Jakarta.

[24] Mustakim. 2012. Cakrawala KB Kependudukan dan Pemberdayaan Keluarga. Referensi. Jakarta.

[25] Pardede, Pontas M. 2005. Manajemen Operasi dan Produksi: Teori, Model, dan Kebijakan. Andi. Jogjakarta.

[26] Pemerintah Kabupaten Tanah Laut. 2019. Rencana Pembangunan Jangka Menengah Daerah Kabupaten Tanah Laut 2018-2023. Dokumen RPJMD 2018-2023, 144-163.

[27] Prijono, Onny S. dan Pranarka, AMW 1996. Pemberdayaan Konsep Kebijanan dan Implementasi. Centre for Strategic and International Studies. Jakarta.

[28] Puspitawati, H. 2013. Ketahanan dan Kesejahteraan Keluarga. Institut Pertanian Bogor.

[29] Rofai. 2006. Analisis Faktor-Faktor Yang Mempengaruhi Efektivitas Organisasi Pada Badan Kesatuan Bangsa Dan Perlindungan Masyarakat Propinsi Jawa Tengah. Program pasca Sarjana Universitas Diponegoro. Semarang.

[30] Santosa, Slamet. 2004. Dinamika Kelompok. Bumi Aksara. Jakarta.

[31] Sarman, Mukhtar. 2004. Pengantar Metodologi Penelitian Sosial. Pustaka FISIP Universitas Lambung Mangkurat. Banjarmasin. 2008.

[32] Program Pemberdayaan Masyarakat Berbasis LERD, Peluang Kalimantan Selatan. Pusat Kajian Kebijakandan Pembangunan Daerah \& Program MSAP Universitas Lambung Mangkurat. 2016. Paradigma Penelitian. Pilihanpilihan Pendekatan. Program Magister Sains Administrasi Pembangunan Universitas Lambung Mangkurat. Banjarbaru.

[33] Sarman, Mukhtar dan Hidayat, Taufik. 2010. Panduan Prosedur Penelitian dan Penulisan Tesis. Program Pasca Sarjana Magister Sains Administrasi Pembangunan Universitas Lambung Mangkurat. Banjarmasin.

[34] Sarwono, Jonathan. 2013. Strategi Melakukan Riset. Andi. Jakarta. 
[35] Sjafari, Agus. 2014. Kemiskinan dan Pemberdayaan Kelompok. Graha llmu. Jogjakarta.

[36] Slameto, 2016. The Application of Fishbone Diagram Analisis to Improve School Quality. DINAMIKA ILMU Vol. 16 No. 1, 2016. Satya Wacana Christian University, Salatiga

[37] Soetomo. 2006. Strategi-Strategi Pembangunan Masyarakat. Pustaka Pelajar. Yogyakarta

[38] Soetrisno, Loekman. 1997. Kemiskinan,Perempuan, dan Pemberdayaan. Universitas Gajah Mada. Yogyakarta.

[39] Soleh, Chabib. 2014. Dialektika Pembangunan Dengan Pemberdayaan. Fokusmedia. Bandung.

[40] Sulistiyani, Ambar Teguh. 2004. Kemitraan dan ModelModel Pemberdayaan. Gava Media. Jogjakarta.

[41] Suranto, AW (2011). Komunikasi Interpersonal. Yogyakarta: Graha Ilmu

[42] Sutanta. 2003. Sistem Informasi Manajemen. Graha Ilmu. Yogyakarta.
[43] Syahyuti. 2007. Kebijakan Pengembangan Gabungan Kelompok Tani (Gapoktan) Sebagai Kelembagaan Ekonomi Di Perdesaan. Bogor: Pusat Analisis Sosial Ekonomi dan Kebijakan Pertanian. Analisis Kebijakan Pertanian. 5 (1): 15 -25 .

[44] Utomo, Tri Widodo. Dkk. 2006. Model Kelembagaan Pengelolaan Kawasan Perbatasan Dalam Rangka Percepatan Pembangunan Sosial Ekonomi Wilayah Perbatasan. Pusat Kajian dan Pendidikan dan Pelatihan Aparatur III Lembaga Administrasi Negara. Samarinda.

[45] Widiastuti, Siti Kurnia dkk. 2015. Pemberdayaan Masyarakat Marginal. Pustaka Pelajar. Yogyakarta .

[46] Wrihatnolo, Randy R. dan Dwidjowijoto, Riant Nugroho. 2007. Manajemen Pemberdayaan. Elex Media Komputindo. Jakarta. 